\title{
"Because My Father Told Me To": Exploratory Insights into Parental Influence on the Retirement Savings Behavior of Adult Children
}

\author{
Lynne Robertson-Rose ${ }^{1}$ (D)
}

Published online: 22 August 2019

(c) The Author(s) 2019

\begin{abstract}
The paper explores the influence of parents on their adult children's retirement saving strategies. Using examples from 25 qualitative interviews the exploratory study shows how financial socialization can continue well beyond adolescence. It offers examples of parents encouraging their adult children to save for retirement and children's reliance upon their parents for advice about pension contribution levels and asset allocation. Parents also provide salient examples—both negative and positive-from which adult children discover for themselves the consequences of earlier savings decisions. The paper's two key points are that parents' financial preparedness for retirement can impact the younger generation's retirement choices and that family financial socialization continues into adulthood.
\end{abstract}

Keywords Financial socialization · Parental influence $\cdot$ Retirement saving · Pensions

\section{Introduction}

The increased reliance in the United Kingdom (UK) upon defined contribution (DC) pensions raises questions about individuals' necessary knowledge and financial skills for retirement. Although there is extensive research into the development of financial capability in young people (Jorgensen and Salva 2010; Johnson and Sherraden 2007; Kim and Chatterjee 2013; Kim et al. 2011; Serido et al. 2010), how financial decision-making skills evolve throughout adulthood is seldom mentioned in the retirement savings literature. Market-linked retirement savings products offer young adults little opportunity to learn from mistakes. Deciding on an appropriate pension contribution rate is complex but the efficacy of those pension savings strategies is rarely apparent until retirement. Although financial advice on pensions is available, Gerrans and Hershey (2017) suggested that anxiety about approaching a financial adviser might act as a barrier to young people seeking professional advice. Another potential avenue to aid decision-making is for young people to use their parents' pension experiences as a guide, or to actively seek their advice. The role that the

Lynne Robertson-Rose

Lynne.Robertson-Rose@ed.ac.uk

1 Social Policy, School of Social and Political Science, University of Edinburgh, Edinburgh, UK family plays in developing savings habits in young adults has been shown to be crucial (Serido et al. 2010; Tang and Peter 2015) but do adult children look to their parents as behavioural models, and do parents continue to help their adult children achieve successful retirement savings strategies?

This paper sheds light on these questions. The author's key argument is that parents' financial capabilities and pension experience can influence their adult children's retirement saving strategies. The paper provides insights from 25 exploratory interviews that show how adult children can be influenced by their parents when planning for retirement. The findings add to financial capability research by demonstrating that parents can play a role in the retirement wellbeing of their adult children by encouraging them to enroll in workplace pension schemes. The study also illustrates how parents provide financial information and guidance to their offspring well into adulthood. This research adds to our understanding of retirement savings behavior by showing that parents provide salient examples-both negative and positive-from which adult children can see for themselves the consequences of earlier savings decisions. 


\section{Early Influences on the Acquisition of Financial Capability}

Well-being in retirement is directly linked to financial literacy and planning during working life (Lusardi and Mitchell 2014). Early work experience introduces financial knowledge and skills which aid the attainment of healthy financial behavior (Shim et al. 2010). Support from employers and work colleagues at the early career stage can also be helpful in developing financial skills and positive savings behaviors (Robertson-Rose 2018). However, the genesis of financial literacy and planning in adults is the acquisition of financial capability earlier in life (Lusardi et al. 2010). Much adult savings behavior is determined by socializing experiences and savings behaviors developed in adolescence (Ashby et al. 2011), and it is believed that low levels of financial literacy in young people persist into adulthood (Lusardi et al. 2010). The extensive research into the financial capabilities of younger adults suggests that skills develop from experiences at school and in the home (Brown and Taylor 2016; Harrison et al. 2017). At the school level, financial education in adolescence increases financial knowledge (Walstad et al. 2010) which leads to changes in attitudes and positive financial behaviors (Xiao and O'Neill 2016). But financial literacy programs on their own are not sufficient to promote positive financial capability (Borden et al. 2008) and Shim et al. (2009) argue that purposive parental financial education is more important to the development of positive financial behavior in young people than schoolbased education.

Young people acquire financial attitudes, behaviors and financial literacy skills implicitly through family interaction and by observing and mimicking adult behavior (Gudmundson and Danes 2011). In addition, purposive parental teaching is important for young people's financial skills acquisition (Jorgensen and Salva 2010) and parental encouragement has been demonstrated to predict higher total saving in young adults (Webley and Nyhus 2006). Conversations about financial matters provide important knowledge for young people (Hanson and Olson 2018). Parents are the primary source of information when young people are seeking information about financial products (Danes and Haberman 2007; Harrison et al. 2017) and parental instruction in financial skills is positively related to financial well-being in college students (Shim et al. 2010). However, although there is an increasing body of literature on the intergenerational transfer of financial capability (Hanson and Olson 2018; Koposko and Hershey 2016; LeBaron et al. 2018), there is a lack of research into the influence of the family once children reach adulthood. Existing research largely focuses on children and late adolescents (Webley and Nyhus 2006). The limited number of studies that have looked at parental influence on younger adults rarely extended their focus beyond the college years. Indeed, parents' influence on their children's acquisition of financial capability is generally considered to be declining as they approach adulthood, ceasing when offspring fully enter the workplace. Thus, most of the studies that have considered the developing financial capabilities of emerging adults focused on their experiences as they entered further education (Allen et al. 2007; Shim et al. 2010), entered work, or reached financial independence (Lee and Mortimer 2009). Researchers identified peers and romantic partners as becoming increasingly relevant as young adults age (Burgoyne et al. 2010; Curran et al. 2018; Koposko and Hershey 2016). Harrison et al. (2017) noted that parents and other family members remain the principal trusted source for financial information for young adults aged 18 to 24 but, thereafter, the relevance of parents all but disappears from the research literature. It is acknowledged that parental saving behavior has a long-lasting influence (Knowles and Postlewaite 2004; Ward 2013) but the assumption appears to be that, beyond residual attitudinal influence, parents have little to teach their adult children about saving for retirement. The extent to which parents are involved in the day-today retirement savings decisions of their adult children is rarely discussed in the savings and financial literacy literature. Gudmundson and Danes (2011) drew attention to the life-course perspective of family financial socialization but, generally, the continuing role of parents is ignored. This current article addresses this gap in the literature.

\section{Intergenerational Similarities in Retirement Savings Behavior}

Theoretical explanations for similarities in intergenerational asset accumulation stress different dimensions of socioeconomic advantage, including intergenerational earnings mobility, occupational mobility, class, and status (see Torch 2015 for a review of the literature). Analysis of these factors has produced mixed findings but much of the existing research suggests that, in the UK, the intergenerational correlation of wealth has a socio-economic explanation. However, Gouskova et al. (2010) argued that, in retirement saving, socio-economic circumstances alone cannot explain this wealth correlation. The literature suggests that similarities in intergenerational pension membership may derive from the early acquisition of financial skills. Koposko and Hershey's (2016) study of college-aged students concluded that early financial influences impact individuals' motives to saving for retirement. Another study, by Gutierrez and Hershey (2014), pointed to parental influences on expected quality of life in 
retirement but did not determine whether the motives and satisfaction remained as individuals age (the direct impact of parental influence on the middle-aged group in the same study was not observed). By contrast, a more recent quantitative study on economic cognitions found that earlier parental socialization predicted financial planning for retirement amongst older adults (Palaci et al. 2017). Other researchers have also noted the impact of parental influence on financial behavior over the longer term (Tang 2017).

But questions remain unanswered. To what extent does the contemporary influence of parents matter? As they reach middle adulthood, do individuals still look to their parents as behavioral models and as sources of retirement savings advice? These are pertinent questions because of the longterm nature of retirement savings planning. Parental behavioral models may no longer be appropriate given that the career trajectories open to the younger generation differ from their parents', and grandparents', most of whom experienced little job mobility. Moreover, the shift from Defined Benefit (DB) to DC pension provision raises questions about the suitability of parental pension advice. Given the limited research into parental influence on financial planning for retirement, there is a need for exploratory qualitative research (Palaci et al. 2017). This current study goes some way to meet that need - the paper reports evidence from 25 qualitative interviews that provide insight into how and why parents remain an active influence on the retirement savings decisions of their children long past early adulthood.

\section{Methods}

The research project was part of an exploratory mixedmethods study that examined reactions to workplace pension scheme default settings (Robertson-Rose 2016) amongst middle-income employees. It was conducted in 2013 during the legislated introduction of automatic enrolment (AE) into UK workplace pension schemes. AE was introduced as a response to the closure of most private-sector DB schemes to new members and a subsequent decline in voluntary workplace pension participation. The study adopted an exploratory approach to examine the retirement savings behavior of 30-40-year-olds.

The author developed the research design to investigate variations in pension contribution levels (the dependent variable). Based on Mill's Method of Difference (MMD) (Mill 1843 ) the study used a parallel case-orientated technique, known to comparative researchers as "most similar systems design" (MSSD), that seeks to resolve the paradox of cases which appear to be similar but in which there is unexplained variation in outcome (Ragin 2014). The aim is to identify differences in the circumstances leading up to the phenomenon under investigation: those circumstance being "the cause or, a necessary part of the cause, of the phenomenon" (Mill 1843, p. 455). In this study, the selection criteria for similarity was based on a theoretical understanding of the explanations for variations in retirement savings behaviorthese included income, age and education (Gough and Niza 2011). Pension scheme architecture, including minimum contribution levels and employers' contribution matches, is also known to influence behavior (Beshears et al. 2009). Controlling for these variables facilitated the search for other explanations for pension contribution variation. As part of the wider study, all of the, approximately 20,000, employees at a UK firm were invited by email to take part in a web-based retirement savings survey. In all, 3457 responses were received of which 886 agreed to further research participation. The researcher interviewed 25 of these individuals, purposively selected on the basis of similarity of age (30-40 years), income (receiving between $£ 27,000$ and $£ 40,000)$ and education (tertiary education). Table 1 lists participant details. The willingness of the participants to take part in additional research would suggest that they took some interest in pensions but they were unaware that parental influence would be a topic of discussion.

The 30 to 40 age group was selected because, at that age, most workers hold some pension provision but are not yet taking an active interest in preparing for retirement. These younger adults' retirement savings are also predominantly invested in DC schemes. The UK average gross income for all full-time employees is around $£ 27,000$ per annum (Office of National Statistics 2017). The research focused on the $£ 27,000-£ 40,000$ group because middle-earners face challenges maintaining income in retirement due to the lack of earning-related state pensions. Most UK residents build up entitlement to a flat-rate state pension but it is not generous and many middle-earners will be reliant on their workrelated pension to supplement income in retirement. Thus, a social policy justification underpins participant selection although this does limit the generalizability of the study findings. All participants had tertiary education-tertiary education is a predictor for increased financial provision for retirement.

All participants had access to the same DC workplace pension scheme and this similarity in pension provision enabled the author to control for the confounding effects of the pension scheme architecture. The default (and minimum) employee contribution was $3 \%$ but members could increase this, or withdraw and re-join the scheme at any time. Contributions into the pension scheme were deducted at source and free of income tax. The employer matched contributions up to $6 \%$ with an additional $3 \%$ long-service bonus after 5 years' service and another 3\% after ten. The company had been voluntarily automatically enrolling new employees into the scheme since the mid-2000s and employees recruited earlier were entitled to join. Participants differed in their 
Table 1 Participant details

\begin{tabular}{|c|c|c|c|c|c|c|c|c|}
\hline & Gender & Age & Family status ${ }^{\mathrm{a}}$ & $\%^{\mathrm{b}}$ & Father $^{\mathrm{c}}$ & Mother & General $^{\mathrm{d}}$ & Ethnic $^{\mathrm{e}}$ \\
\hline A & Male & 30 & Partnered, no children & 6 & Semi-retired, DB pension & Working, DB pension & & WB \\
\hline B & Female & 33 & Re-partnered, children & 3 & Still working, little pension & Deceased & & WB \\
\hline $\mathrm{C}$ & Male & 35 & Partnered, no children & 6 & Comfortably retired & Comfortably retired & & WB \\
\hline $\mathrm{D}$ & Male & 32 & Single, no children & 9 & $\begin{array}{l}\text { Retired ill-health little } \\
\text { pension }\end{array}$ & Still working & & WB \\
\hline $\mathrm{E}$ & Female & 40 & $\begin{array}{l}\text { Divorced, re-partnered, } \\
\text { children }\end{array}$ & 6 & $\begin{array}{l}\text { Comfortably retired on DB } \\
\text { pension }\end{array}$ & Deceased & Father job-for-life & WB \\
\hline $\mathrm{F}$ & Male & 37 & $\begin{array}{l}\text { Divorced, re-partnered, } \\
\text { children }\end{array}$ & 6 & Retired on DB pension & $\begin{array}{l}\text { Divorced, still working, DB } \\
\text { pension }\end{array}$ & Father job-for-life & WB \\
\hline $\mathrm{G}$ & Female & 34 & Single, no children & 3 & Retired on DB pension & Housewife, little pension & Father job-for-life & WB \\
\hline $\mathrm{H}$ & Female & 40 & Divorced, children & 8 & $\begin{array}{l}\text { Divorced comfortably } \\
\text { retired on DB }\end{array}$ & $\begin{array}{l}\text { Divorced, comfortably } \\
\text { retired }\end{array}$ & Parents abroad & WB \\
\hline I & Female & 31 & Partnered, no children & 3 & $\begin{array}{l}\text { Working, pension probably } \\
\text { DB }\end{array}$ & $\begin{array}{l}\text { Divorced, self-employed, } \\
\text { un-pensioned }\end{array}$ & & WB \\
\hline $\mathrm{J}$ & Male & 39 & Partnered, no children & 6 & Retired on DB pension & & & $\mathrm{AB}$ \\
\hline $\mathrm{K}$ & Female & 35 & Partnered, no children & 6 & Comfortably retired & Comfortably retired & & WB \\
\hline $\mathrm{L}$ & Male & 39 & Single, no children & 6 & Comfortably retired & Comfortably retired & & WB \\
\hline M & Male & 36 & Partnered, children & 3 & $\begin{array}{l}\text { Retired ill health, DB pen- } \\
\text { sion }\end{array}$ & Still working, DC pension & & WB \\
\hline $\mathrm{N}$ & Female & 35 & partnered, no Children & 0 & Comfortably retired & $\begin{array}{l}\text { Comfortably retired on DB } \\
\text { pension }\end{array}$ & Parents abroad & $\mathrm{BA}$ \\
\hline $\mathrm{O}$ & Male & 32 & Partnered, children & 3 & Comfortably retired & & & WB \\
\hline $\mathrm{P}$ & Male & 34 & Partnered, no children & 7 & Comfortably retired & Comfortably retired & & WB \\
\hline Q & Male & 39 & Single, no children & 6 & Comfortably semi-retired & $\begin{array}{l}\text { Comfortably retired on DB } \\
\text { pension }\end{array}$ & Mother job-for-life & WB \\
\hline $\mathrm{R}$ & Female & 34 & Divorced, children & 6 & & Divorced, little pension & & WB \\
\hline $\mathrm{S}$ & Male & 37 & Partnered, children & 3 & Still working, pensions & Still working, pensions & Parents abroad & $\mathrm{BA}$ \\
\hline $\mathrm{T}$ & Female & 30 & Single, no children & 3 & Still working & Still working & & WB \\
\hline $\mathrm{U}$ & Male & 37 & Partnered, no children & 0 & Comfortably retired on DB & Comfortably retired on DB & Parents job-for-life & WB \\
\hline $\mathrm{V}$ & Female & 33 & Partnered, no children & 6 & Still working, little pension & Still working, little pension & Parents abroad & WEU \\
\hline $\mathrm{W}$ & Male & 35 & Partnered, no children, & 0 & DC pension & Housewife & & WB \\
\hline $\mathrm{X}$ & Male & 30 & Partnered, no children & 5 & Still working, DB pension & & & WB \\
\hline $\mathrm{Y}$ & Female & 33 & Partnered, children & 3 & Still working, DB pension & Little pension & Father job-for-life & WB \\
\hline
\end{tabular}

To preserve anonymity, details that might lead to identification of participants are not listed. This includes participants' job description and work location (which ranged from northern Scotland to southern England and from inner-city to rural locations)

${ }^{a}$ Marital status and parenthood status where known

${ }^{b}$ Employee contribution into pension scheme as percentage of salary

'Father/Mother denotes parents' employment status and probable DB or DC pension provision. Most participants did not specify DB or DC status but in some cases, based on occupation, pension provision could be identified by the researcher. Participants' perception of parents' financial security is listed where recorded

${ }^{\mathrm{d}}$ This column notes where a parent was employed at a single employer for the bulk of their working life and likely to have built up a good pension

${ }^{e}$ Ethnicity: $A B$ Asian British, $B A$ Black African, $W B$ White British, $W E U$ White European

pension preparedness- $\mathrm{a}$ few had been saving into pensions their entire working lives but several had contributed for fewer than 5 years. Three participants were not enrolled in the workplace pension at the time of the interviews; eight contributed $3 \%$ of salary, and other contributions ranged from 5 to $9 \%$ (Table 1). Most invested in the scheme's default managed investment fund. All participants possessed some retirement savings.

The author conducted face-to-face interviews using a preprepared but open-ended interview schedule with the aim of building up a history of participants' engagement with pensions. She used inductive thematic saturation techniques to determine the sample size (Saunders et al. 2018). However, 
practical limitations meant that the gendered dimension of intergenerational relations, which is highlighted in the results, was not fully explored. Future research would benefit from specifically investigating differences in paternal and maternal influence.

The one-hour interviews, which were held in workplace cafes at six locations across the UK, were recorded, transcribed and coded into NVivo. The initial open-coding involved the organization of the data using descriptive coding and initial-pattern coding to identify commonalities and differences. Coding and analysis was subject to peer review. Emergent themes were used to inform the questioning in the subsequent interviews. Use was then made of the constant comparative method in which the newly-acquired interviews were compared to the existing data. In this way, the data collection and analysis developed as an iterative process.

The ontological position underpinning the research is that the social world is constructed and that in-depth interviews would enable the participants to provide a rich account of how they experienced saving for retirement. The epistemological approach involved reasoning inductively from the data and adopting a critical and reflective stance. The interviews can tell us about the nature of intergenerational relations and they can give us examples of the diversity of experiences in the sample. But what the research cannot tell is whether parental influence on retirement savings behavior is prevalent in other populations. However, this limitation, of a lack of generalizability, needs to be weighed against the advantages of using qualitative methods to meet the study's exploratory aims. Although the findings relate only to the studied participants, the reflexive and conceptual demands of the project "contribute to [its] analytic generalization" (Polit and Beck 2010, p. 1455).

\section{Research Findings}

\section{Survey Results}

The survey asked respondents to identify where they had sought obtained financial advice prior to their decision to contribute to their workplace pension scheme. Responses included: did not seek advice, $46 \%$; parents or other family, $15 \%$; colleagues, $13 \%$; partner/spouse, $10 \%$; friends, $4 \%$; independent financial adviser 3\%; human resources personnel $3 \%$, other $3 \%$, and internet $3 \%$ (Note: figures do not add to 100 due to multiple selections).

The sample selected for interview was less likely than the wider survey population to have sought "no advice". The likelihood of seeking financial advice has been positively associated with education (Collins 2012) and so, given the participants' tertiary education, this finding is not unexpected. Ten of the interviewees had sought "no advice", seven sought advice "from family members", six from their "spouse" and five from "colleagues" or "HR professionals." (The research findings relating to the influence of colleagues on retirement savings behavior is reported in Robertson-Rose 2018). No participant selected "friends" as a source of advice; one consulted an "independent financial adviser" and one failed to answer the question. Most participants only considered one source of advice although there was some overlap between family advice and partner advice. The survey did not ask about ongoing financial advice and guidance but this was explored more deeply in the qualitative interviews.

\section{Interview Results}

It has long been recognized in financial capability research that similarities between the socio-economic position of parents and their offspring can make it difficult to interpret results. In this study, fathers' occupational skill levels, where reported, were primarily upper-middle (skilled trades, selfemployed, lower managerial) although a few were professional. Mothers were generally lower-skilled. It is probable that many of the parents were financially secure during most of their working lives. Most respondents reported that their fathers were likely to enjoy a comfortable retirement, although the mothers' positions, independent of the fathers', were, in most cases, more precarious. Participants' views on their parents' pension provision are noted in Table 1.

The analysis identified four themes. Firstly, parents' attitudes towards saving, and, more specifically, their retirement saving strategies, influenced their children's attitudes toward pensions. Secondly, participants looked to their parents' lives as exemplars of how their own lives might turn out in retirement and there appeared to be a gendered element to this. Thirdly, many of the participants sought financial advice from their parents, and particularly from their fathers. And finally, individuals without parents to turn to for pension advice identified this as an explanation for their own lack of understanding about pensions.

\section{Theme 1: Parents Influencing Attitudes to Saving for Retirement}

Although most participants had not sought parental advice before joining the workplace pension scheme, all drew connections between parental influence and their own financial attitudes. All acknowledged the role that parents had played in developing their financial values. S (male age 37, contributing 3\%) typified this when he remarked that "from the tender age we were told to save, told to be savers for the future." One-third of the participants directly attributed their own retirement savings behavior to parental influence. Parents were mentioned as: having offered direct encouragement to 
save for retirement, acting as exemplars of "good" retirement savings behavior, and as sources of information and advice. The approach that the parents adopted in their pension saving often mirrored the respondents' approach to their own saving. If the parent valued saving for retirement then, in addition to general saving, there was encouragement to join a pension scheme, even if, as A (male age 30,6\%) reflected, this was not the individual's immediate priority. "He (father) always encouraged me to plan ahead, which was difficult as a teenager to think about retiring." Proactive instruction from a parent was not always immediately effective but did appear to establish foundations for future parent-child dialog about pensions.

A handful had fathers, like Q's (male age 39,6\%), who "insisted pretty much" that they enrolled in a pension scheme. Indeed, in some cases, the participants appeared to have joined the pension scheme to avoid parental disapproval. Individuals who might, by other definitions, be considered autonomous adults still sought to establish their financial competency with their parents. As G (female age $34,3 \%$ ) explained, "When my mother goes, 'do you have a pension?' I can go 'yes I do, yes Mummy, I have a pension.'" So, although the parents were not necessarily actively involved in pension decision-making, nor always kept informed about their child's pension arrangements, parental approval was a contributory factor in the decision to start saving for retirement.

A few participants expressed a proactive ethos that echoed their fathers' savings strategies-contributions needed to be more than the minimum contribution set down by the scheme parameters. Some fathers had made additional voluntary contributions into their occupational pensions schemes. In the case of P (male age 34, 7\%), the mechanics and consequences of this approach had been successfully transmitted across generations and exerted a direct effect on his pension contributions. In explaining his reasons for first enrolling in a pension scheme, he remarked that it was,

Mainly down to influences from my parents, my father, in particular, who, for whatever reason, every time he moved companies, started another pension scheme but continued to pay into his previous one. It's paid dividends now, but it's always been something he has kind of pushed hard.

The interviews suggest that parental encouragement exerted a greater influence on pension scheme membership than on personal setting of contribution levels. Although parental savings attitudes influenced the participants' pension scheme enrollment, there was much less evidence of parents directly influencing the amount being saved or the investment fund selection. So, although some participants attributed their pension membership to parental encouragement, close examination of those participants' contribution rates did not offer conclusive evidence of a direct association between contribution levels and parental influence.

\section{Theme 2: Parental Lives as Exemplars}

Several participants drew attention to the positive outcomes that their parents and, in particular, their fathers, had gained through saving for retirement and they made connections between those experiences and their own willingness to save to achieve similar outcomes. Participants appeared to base their retirement expectations and ambitions on those family members closest to them. A (male age 30,6\%) typified this view. "(My father) is retired, is working part-time for the Council, and has a pretty comfortable life. And so if I can aspire to have a life like that when I'm in my late fifties that would be nice."

Interviewees based their hoped-for retirement age on their parents, many of whom retired in their fifties. Most acknowledged that they might need to work longer than their parents, and a few thought that they would be working into their seventies but expected retirement ages were usually below the current state pension age. Several mentioned retiring at around aged 60 . The desire to retire early influenced how participants approached obtaining multiple sources of retirement income. Those who reflected upon how their parents had achieved early retirement were more likely to be proactive about saving. For example, P (male age 34, 7\%), talking about his father's multiple pension investments, said,

It has also allowed him to retire at 55. So, watching him, he is extremely tight with his cash and likes to squirrel it all away, but you see the dividends of it in the end. So, that has probably been the biggest driver for me in terms of being very proactive about it.

Participants referred to long careers, accumulation of housing wealth and pension wealth. There was some awareness, as A (male age 30,6\%) noted, that parents' "family circumstances would have been different," but little reflection upon the details of their parents' experiences. In most cases, the route to parental pension security involved structural factors, such as lifelong secure employment, property ownership and largely passive DB pension scheme membership. The difference in economic circumstances between generations was rarely brought to the fore, except as a positive narrative about upward mobility. Several participants referred to fathers who did not benefit from higher education but who retired comfortably. The knowledge that most children possessed about their parents' pensions was limited but they could see examples of parents retiring early or being comfortably retired and there seemed to be an underlying assumption that replication of their behavior would lead to similar retirement outcomes. 
Although it was generally believed that the occupational pensions available to the current generation were less generous than for their parents' generation, few reflected on the differences between DB and DC schemes. It was rare for participants to draw attention to their parents having been in DB schemes-even if this was probable. Parents appeared to have communicated the point that enrollment in a workplace pension is important for building up benefits but there is little evidence of discussions about relevant technical issues. For example, only one participant made reference to annuities. This lack of attention to the pension scheme architecture may explain why modelling behavior was prevalent for scheme membership but appears to be less relevant to contributions levels.

\section{Negative Parental Experiences-The Gender Dimension}

Several of the women spoke about their worries for their mothers' financial position in retirement. The evidence from this study suggests that the mothers' pension situation had an impact upon how some female participants approached pension saving. For example, a few blamed their own perceived lack of financial preparedness or financial skills on their mothers' shortcomings. I (female age 31, 3\%) said, "My Mum obviously she's not in control of her own finances as far as from my perspective. She has never sat down and kind of explained any of that to me." But it is not clear whether having a mother with little financial literacy was being offered as a justification for low pension savings or was a cause of it. Lack of maternal financial skills or pension preparedness was not offered as an explanation for their own behavior by any of the men in the study. Moreover, the financial position and knowledge of the mothers may have been caused by structural gender inequality-as Y (female age $33,3 \%$ ) noted, when discussing why her mother possessed few retirement savings, "it was common to most women of her generation." One cannot assume that the same social and structural forces experienced by the mothers act upon the participants themselves. Three of the women who mentioned low maternal retirement savings were themselves only contributing $3 \%$ into the workplace pension scheme, Neverthe-less it seems probable that having a parent who was not adequately financially prepared for retirement might have encouraged reflexivity about pension saving. Concerns about parental well-being in retirement appeared to act as a catalyst for thinking about finances. For example, R (female age $34,6 \%$ ), who was proactive about her own pension arrangements, remarked, "My Mum doesn't have a pension and that scares me every day."

Participants rarely referred to their fathers' lack of preparation, primarily because most participants grew up in a household with a working male who was a member of a pension scheme. A couple had seen their fathers retire early through ill-health and this experience encouraged pension scheme enrollment. But there was evidence that negative parental experience regarding market-linked pensions had a bearing on attitudes to scheme membership. For example, as the quote below illustrates, $\mathrm{W}$, (male age $37,0 \%$ ) who had opted out of the occupational pension scheme, felt that saving into a pension was a fruitless exercise. He linked this to his father's experience.

Yeah, I mean, when I guess I was a teenager, my Dad was self-employed and in a private pension. It was one of the earlier whole-market products ${ }^{1}$ and, in the early nineties, when the housing market crashed and there was a recession, he saw a lot of money in that pension wiped out and obviously, that same thing happened fairly recently for a lot of people. So, you know, that sort of uncertainty makes it a bit of a fool's errand.

There appeared to be a gendered element with sons emulating their fathers (both preparedness and type of preparedness) but some daughters drawing cautionary lessons from their mother's circumstances.

\section{Theme 3: Parents Providing Financial Information}

A recurrent theme was that participants turned to their parents, in particular to their fathers, for financial advice. G (female age 34, 3\%) noted, "I would probably speak to my Dad in the first instance and see what he's got set up." F (male age 37, 6\%) remarked, "I have always had quite good advice from him [my father]." J (male age 39, 6\%) emphasized the importance of his father's advice, "my understanding comes directly from him [my father]. I don't know where or what other source I would have for it." But although participants like $\mathrm{K}$ (female age 35, 6\%) has joined the pension scheme because her father said "it was the right thing to do", only in a very small number of cases was there evidence of parents taking a proactive stance in informing and advising their offspring on pension contribution rates. Q (male age $39,6 \%$ ) whose father had worked in the financial services exemplified this when he said, "again with my Dad's input as well. We had a look and we just upped it a little bit, you know, just to try and get a little bit of decent return on it so to maximize the return a little bit."

Additionally, there is evidence of parents passing on selective financial information that shifted the focus from pension contributions to other investments or to debt reduction. I (female age 31, 3\%) commented,

\footnotetext{
${ }^{1} \mathrm{~W}$ is referring to personal pensions that were heavily promoted in
} the UK in the $1980 \mathrm{~s}$. 
My aim is to pay my mortgage in the next 10 years ... but that's him [my father] telling me that, "you should pay off your mortgage, Go on this calculator. You can take seventy grand off your mortgage," but he never really speaks about pensions.

The father's emphasis on mortgage redemption and his failure to discuss pension saving might not have caused his daughter to focus on her mortgage rather than pension saving, but is reasonable to assume that it could be a contributory factor.

There was other evidence of participants directing funds into mortgages as a long-term strategy, rather than increasing pension contributions. Some parents had invested in property to provide retirement income, and children were generally better informed about the value of their parents' properties and mortgages than their pensions. Two participants previously opted out of the workplace pension scheme to build up property investment and this behavior drew parallels with their fathers' behaviour. O (male age 32, 3\%) appeared to be engaging in mimetic behavior, copying his father's investment strategy. He emphasized the connection between his father's earlier savings behavior and his early retirement.

The reason he retired is because he invested. Because he bought multiple properties and he got into shares at the right time and pensions and all the rest of it so he accumulated enough to go early. I learned good practice from my father.

None of the participants referred to their grandparents as sources of influence or advice but they featured as examples of the positive consequences of saving for retirement. M (male age 36, 3\%) expressed this view when he said, "Both of them have paid into pension schemes and there is no struggling for them." It was noticeable that siblings were seldom mentioned as sources of financial advice. Participants talked about their brothers and sisters but these conversations tended to focus on family members who were less well-off. The vulnerable sibling was presented as an object of familial concern to whom they might provide financial advice. By contrast, participants were less forthcoming about siblings whom they saw as more financially secure and they were less informed about their retirement preparations. Individuals appeared to be unwilling to admit to having received or asked for financial advice from a more successful sibling (although that is not to say that this help was not provided). The relationship between siblings' retirement preparedness and how the dynamic of cooperation and sibling rivalry fits into the larger network of intergenerational asset transfer is certainly worth exploring further.

A final point to note about the intergenerational transfer of financial advice is that, in a few cases, this was a two-way process. D (male age 32, 9\%) remarked that "my Dad even comes to me for financial advice". A couple of other participants had begun to take a greater interest in their parents' financial well-being and were offering them advice as they approached retirement. This suggests that there is merit in Curran et al.'s (2018) proposal to investigate whether the intergenerational financial socialization process ceases to be hierarchical as children age.

\section{Theme 4: The Salience of Missing Parents}

Not all the participants had a parent readily available to turn to for pension advice. Four participants had parents living abroad and another two had a parent who had died. A disadvantage of not having an accessible parent was the lack of opportunity to discuss financial matters face-to-face. Another difficulty was unfamiliarity with the UK state and workplace pension system. Differences between the social security in the home country and the UK meant that the parents living overseas lacked the necessary information to adequately advise their children. $\mathrm{N}$ (female age $35,0 \%$ ) recognized this disadvantage and remarked,

If I had someone, let's say my parents were here and they worked here and lived here and I would be able to go back to them and say "how does this work for you?" and things like that but because I don't really have anyone that I can go to, that makes it a lot more difficult.

When looking to their parents' and grandparents' experiences to guide their behavior, some participants encountered models that were not necessarily appropriate to the UK. For example, V (female age 33, 6\%) came from a society where multigenerational living was the accepted norm. She talked about providing caring support for the older generation and the intergenerational transfer of family houses but possessed little knowledge of pension arrangements.

Having a parent who had died prior to retirement was given as a reason both for not increasing pension contributions and for contributing to the pension. Two women, E (age 40,6\%) and B, (age 33, 3\%) lost their mothers in young adulthood and this affected their behavior. E referred to parental death as "losing your role models" and noted, "you kind of look to your parents to provide you with some sort of guidance, don't you?" But, in addition to losing guidance, she found it hard to imagine a future where she, herself, would be elderly. The salience of maternal early death and, by extension, the possibility of her own premature death, also moderated the resources directed towards saving for retirement, shifting the balance towards lifetime experiences and building up resources for her child. As she sought to achieve a balance between current spending and saving for retirement, she explained how premature maternal death recalibrated her priorities. 
That's why I am not overly-committing to a pension now because I think there is time to do that in the future and I might not even make it.

Following an earlier life-threatening illness, B 's widowed father drew his occupational pension early and distributed the funds amongst his children. B reflected on how his consequent reduced pension assets now impacted her own approach to pension saving. "So, yeah we probably haven't had the best kind of teachers in terms of finances. I am trying to learn lessons from that perspective." From being someone who had previously not saved, she was now "becoming the practical one." Her concerns about her father's financial insecurity in retirement made her consider how lack of pension preparation could affect her own children. She voiced these concerns as justification for recently joining the pension scheme.

I'd never want my children to be in the same situation as me where you are worrying about whether your parents are going to afford to even house themselves, you know, as they get older.

The first case suggests that parental loss can encourage a sense of resignation that restrains retirement saving, but the second case suggests that parental loss and illness can also encourage retirement saving. Although these findings appear to be contradictory, different outcomes may be explained by the interplay of other factors. Brown and Vickerstaff (2011) noted that social capital, empowerment, coping skills, and insight explain variations in constructing narratives about the future.

Although most participants had discussed pensions with their parents, this experience was not universal. $\mathrm{T}$ (female age 30,3\%) claimed no knowledge of her parents' pension circumstances. She also had very little awareness of her own pension and did not know her contribution rate. $\mathrm{U}$ (male age $37,0 \%)$ recognized that his savings values came from his parents because "indirectly, just from their own behavior, you follow it through," but remarked that pensions "wasn't something that I ever discussed with my parents."

In the absence of parental advice, participants sought guidance from older work colleagues (see Robertson-Rose 2018 ) or spouses. V, (female age 33,6\%), whose parents lived abroad, referred to her husband as her main source of advice about pensions and it was evident that other couples combined information. Indeed, even if an individual did not have an informed parent of their own, they could benefit from a parent-in-law's knowledge. J (male age 39, 6\%) talking about his partner, noted that "she's quite keen we go to visit my parents or they come down here to get some advice from my Dad."

The participants in this study all held well-paid jobs and many had benefited from a financially secure upbringing.
The advantages of their having a parent with a positive attitude to saving exerted influence beyond the individual and could beneficially impact their partners. For example, $\mathrm{F}$ (male age 37,6\%) spoke about how he tried to use the financial capability he acquired from his parents to compensate for his wife's lack of positive role models.

Her Dad, for instance, he was never in well-paid jobs. And I have asked him about pensions and he would always say, "no, never put into pensions, waste of time, waste of money, you always lose money." And stuff like that. He has always been quite negative, so my partner, she has kind of took up the same kind of thing. I try to educate her a little bit, savings and insurance and things like that. I think it is because my Dad has had quite good result obviously out of his.

This quotation raises questions that are beyond the scope of the current study. Was there something in the backgrounds of the participants that led them to acquire education and higher-paying occupations? Was the financial dialog between some of these adult children and their parents a natural result of earlier years of discussion about other topics including education and work? The direction of causality is not clear. It may be that parents who are willing to discuss their retirement arrangements have more financially secure adult children, or it may be that financially secure adult children are more willing to talk about pensions with their parents. A similar study focusing on low-paid employees would be illuminating.

\section{Discussion}

This research suggests that parents can play a role in the retirement financial well-being of their adult children by helping them develop retirement savings values. The study offers examples of parents providing ongoing information and guidance about pensions. There was a gendered element to this advice, with much greater reliance on fathers than on mothers. Thirdly, the findings add to our understanding of how financial capability develops over the life course by showing that some parents provide examples-both negative and positive-from which adult children can see for themselves the consequences of earlier savings decisions. The salience of these examples changes over time as children and their parents age.

The study provides evidence confirming Gudmundson and Dane's (2011, p. 662) assertion that "financial socialization occurs throughout life". Although, in most cases, parental influence seemed to exert little direct influence on the level of pension contributions, parental savings behavior created the context in which the participants considered saving. Those participants who identified parental encouragement 
to join pension schemes appeared to experience earlier enrollment and more continuous contribution records. This finding supports research into the linkages between early and later savings behavior in adulthood (Ashby et al. 2011). The salience of their parents' financial position influenced individuals' approaches their own retirement planning, particularly with regard to diversification strategies. Whether participants favored pensions or property investment depended to some extent on the positive experiences of their parents. These findings are in keeping with theories of financial socialization that suggest modelling as a likely conduit for financially-orientated behavior (Webley and Lea 1993). However, references that some participants made to parental approval of their actions suggest that modelling is not the only explanation for similarities in intergenerational behavior in adulthood. At this juncture, a caveat needs to be inserted-the socio-economic background of the participants will have had some impact on their social expectations and the degree and type of parental support (Fingerman et al. 2015). We cannot assume that parental influence in favor of pension scheme enrollment will be equally relevant to social groups other than the one in the study.

Parents provided information and guidance about pensions. But, probably because most parents had been members of DB schemes and their knowledge was now obsolete, they appeared to exert little direct impact on participants' assessments of the suitability of contribution levels. However, parents were a trusted source of financial advice and this was especially pertinent where parents expressed a preference for non-pension avenues of asset building, such as property investment. An important consideration is that, although the socio-demographic range of the sourced interviews was narrow (and relatively economically privileged), the variation in practical parental involvement was considerable. Some parents actively advised their children, particularly when they possessed knowledge of financial products, and this suggests that parental financial planning skills and an understanding of DC schemes could be important in explaining variation in pension contribution levels. This observation adds to the development of family financial socialization theory by highlighting that, although much family financial socialization is implicit, sometimes intentional explicit socialization is still relevant well into adulthood. A further avenue of research would be to investigate explicit parental input using a wider demographic.

For a few of the participants, having a parent who was not adequately financially prepared for retirement encouraged them to think about pension saving. This finding goes some way to answering the question raised by Palaci et al. (2017) regarding the extent of negative socialization on economic decisions. Palaci et al. also questioned whether a father's influence on his children is greater than a mother's. Amongst the women in this study, their fathers had greater informational influence than their mothers and although both sexes turned to their fathers for advice, none mentioned asking their mother. Agnew and Cameron-Agnew (2015) found that fathers play a larger role in financial discussions with children than mothers do and this current study illustrated that this effect persists well into adulthood. However, there may be a straightforward explanation for participants asking their fathers for financial advice. It could be that adult children rely on the family's financial manager and that for most of the study participants this was their father. Agnew and Cameron-Agnew (2015) also conjectured that that high paternal education levels are more influential than high maternal education levels. An alternative hypothesis is that it is the parent with the better-paid career who most influential. A further study investigating the link between income and gendered financial advice would be illuminating.

Some mothers had their own employment pensions but there was a gendered difference in how participants reported parental pension provision. Sons usually ignored their mothers' position as an individual and referred to their fathers or to their parents collectively. This was probably because the fathers had better pension provision, but it might also have been because fathers were seen as playing the dominant financial role. The mothers' financial situation had greater salience with the daughters and they expressed more concern about mothers with little individual pension provision. One possibility is that the women more readily identified with the potential financial vulnerability that comes from the loss of a higher-earning spouse. It is difficult to draw conclusions because the sample was small. Confounding influences, such as the daughters' socio-economic position or marital and childbearing status, might have affected their view of their mothers' economic security.

As their parents and grandparents aged and approached retirement, the participants in this study developed a gradual realization of the significance of saving for retirement. It has long been recognized that attitudes to retirement saving change as we age (Hershey et al. 2010). This study suggests that having aging parents provides evidence of the consequences of savings strategies that, because of the extended nature of retirement savings contracts, are not usually obvious at their inception. Thus, increased interest in pensions as we age may not just be a response to changes in our own life-course but may also be a response to changes in the lives of previous generations. Arguably a lack of older role models, for any reason, could make it difficult for individuals to develop appropriate savings strategies.

As previously discussed, the generalizability of this paper's findings is limited by the purposive sampling and qualitative methods that were adopted to meet the social policy and exploratory aims of the research. An additional issue is that research interviews rely on interviewees being honest. The tendency to respond to questions in a socially 
acceptable way (social desirability response bias) may have influenced the participants to over emphasize parental agency and positive outcomes. The participants' understanding of their parents' pension position could also have been based on incorrect assumptions. These beliefs and assumptions, are important because they will have influenced participants' behaviour. Never-the-less one should be cautious about unequivocally accepting the participants' version of events. Additional research would benefit from including independent verification of parental circumstances in its research design.

\section{Conclusion}

This research showed that parental financial influence can persist into adulthood. Parents do act as behavioral models and as sources of retirement savings advice for their grownup children. Although researchers largely ignore family financial socialization in adulthood, this research demonstrates that parental influence on their children's retirement savings strategies can persist over time. Thus, the study answers the question, posed by Curran et al. (2018), of whether financial socialization continues into adulthood.

The findings are significant because they provide insights into how the experiences (both positive and negative) of previous generations can contribute to developing the financial capability of the next. That is important because this study is one of the few that considers the links between parental financial socialization and retirement savings behavior. It suggests that cross-generational influences are relevant to both financial capability research and retirement savings behavior research.

In the UK, in recent years, attention has been directed to encouraging early engagement with retirement saving through automatic enrollment. Implicit in this policy is an assumption that young adults will benefit from being inculcated at an early age into the norms of saving for retirement. At the same time, efforts are being made to raise financial literacy amongst the young. This study suggests that a family-orientated approach to financial education, targeting appropriate intergenerational knowledge transfer, could have a positive impact on helping the younger generation increase their retirement savings. This finding has implications for the UK's newly-formed Money and Pension Service (MAPS) which has brought financial and pension advice bodies together under one umbrella organization. Advice practitioners need to embrace the cross-generational dimension of financial competency acquisition and encourage the intergenerational transfer of information and skills. This is especially important in retirement planning because of the long time-periods involved.
However, the author also injects a note of caution. Although the participants in this study recognized that social conditions had changed since their parents were young, few understood the significant differences between DB and DC schemes. They largely ignored the risks inherent in the individualization of assets in DC pension schemes. This latter point is of importance to pension policymakers. The study focused on middle-earners, and, from a UK perspective, this attention is highly relevant because of the meager flat-rate state pension. To maintain their current income levels into retirement, middle-earners need to save relatively more of their earnings than the lower paid. The risk is that those middle-earners whose parents are relatively prosperous in retirement may not understand how reliant their parents are upon their DB pension provision (and, indeed, on their housing wealth). Emulating their parents' saving strategies may not be sufficient to build an adequate pension in an evolving DC pensions environment. Policymakers should not treat current pension policy in isolation and need to recognize that the residual effects of past policies may also impact the retirement savings behavior of the younger generation.

Acknowledgements The author thanks Professor Jochen Clasen and Professor Alison Koslowski of the University of Edinburgh for their comments on this paper.

\section{Compliance with Ethical Standards}

Conflict of interest The author declares that they have no conflict of interest.

Ethical Approval All procedures performed in studies involving human participants were in accordance with the ethical standards of the University of Edinburgh Research \& Research Ethics and Integrity Committee and with the 1964 Helsinki declaration and its later amendments or comparable ethical standards.

Informed Consent Informed consent was obtained from all individual participants included in the study. Additional informed consent was obtained from all individual participants for whom identifying information is included in this article.

Open Access This article is distributed under the terms of the Creative Commons Attribution 4.0 International License (http://creativeco mmons.org/licenses/by/4.0/), which permits unrestricted use, distribution, and reproduction in any medium, provided you give appropriate credit to the original author(s) and the source, provide a link to the Creative Commons license, and indicate if changes were made.

\section{References}

Agnew, S., \& Cameron-Agnew, T. (2015). The influence of consumer socialization in the home on the gender differences in financial literacy. International Journal of Consumer Studies, 39, 630-638. https://doi.org/10.1111/ijcs.12179. 
Allen, M., Edwards, R., Hayhoe, C., \& Leach, L. (2007). Imagined interactions, family money management patterns and coalitions, and attitudes toward money and credit. Journal of Family and Economic Issues, 28, 3-22. https://doi.org/10.1007/s1083 4-006-9048-1.

Ashby, J., Schoon, I., \& Webley, P. (2011). Linkages between saving behavior in adolescence and adulthood. European Psychologist, 16, 227-237. https://doi.org/10.1027/1016-9040/a000067.

Beshears, J., Choi, J., Laibson, D., \& Madrian, B. (2009). The importance of default options for retirement saving outcomes: Evidence from the United States. In J. Brown, J. Liebman, \& D. Wise (Eds.), Social security policy in a changing environment (pp. 167-195). Chicago: University of Chicago Press.

Borden, L., Lee, S.-A., Serido, J., \& Collins, D. (2008). Changing college students' financial knowledge, attitudes, and behavior through seminar participation. Journal of Family and Economic Issues, 29, 23-40. https://doi.org/10.1007/s10834-007-9087-2.

Brown, S., \& Taylor, K. (2016). Early influences on savings behavior: British panel data. Journal of Bank Finance, 62, 1-14. https://doi. org/10.1016/j.jbankfin.2015.09.011.

Brown, P., \& Vickerstaff, S. (2011). Health subjectivities and labour market participation: Pessimism and older workers' attitudes and narratives around retirement in the United Kingdom. Research on Aging, 33, 529-550. https://doi.org/10.1177/0164027511410249.

Burgoyne, C., Reibstein, J., Edmunds, A., \& Routh, D. (2010). Marital commitment, money and marriage preparation: What changes after the wedding. Journal of Community \& Applied Social Psychology, 20, 390-403. https://doi.org/10.1002/casp.1045.

Collins, M. (2012). Financial advice: A substitute for financial literacy. Financial Service Review, 21, 307-322. https://doi.org/10.2139/ ssrn.2046227.

Curran, M. A., Parrott, E., Ahn, S. Y., Serido, J., \& Shim, S. (2018). Young adults' life outcomes and well-being: Perceived financial socialization from parents, the romantic partner, and young adults' own financial behaviors. Journal of Family and Economic Issues, 39, 445-456. https://doi.org/10.1007/s10834-018-9572-9.

Danes, S., \& Haberman, H. (2007). Behavior: A gendered view. Journal of Financial Counseling and Planning, 18, 48-60.

Fingerman, K. L., Kim, K., Davis, E. M., Furstenberg, F. F., Birditt, K. S., \& Zarit, S. H. (2015). "I'll give you the world": Socioeconomic differences in parental support of adult children. Journal of Marriage and Family, 77, 844-865. https://doi.org/10.1111/ jomf.12204.

Gerrans, P., \& Hershey, D. A. (2017). Financial adviser anxiety. Financial literacy, and financial advice seeking. Journal of Consumer Affairs, 51, 54-90. https://doi.org/10.1111/joca.12120.

Gough, O., \& Niza, C. (2011). Retirement savings choices: Review of the literature and policy implications. Population Ageing, 4, 97-117. https://doi.org/10.1007/s12062-011-9046-4.

Gouskova, E., Chiteji, N., \& Stafford, F. (2010). Pension participation: Do parents transmit time preference. Journal of Family and Economic Issues, 31, 138-150. https://doi.org/10.1007/s1083 4-010-9181-8.

Gudmundson, C., \& Danes, S. (2011). Family financial specialisation. Journal of Family Economic Issues, 32, 644-667. https://doi. org/10.1007/s10834-011-9275-y.

Gutierrez, H. C., \& Hershey, D. A. (2014). Age differences in expected satisfaction with life in retirement. The International Journal of Aging and Human Development, 78, 93-114. https://doi. org/10.2190/ag.78.2.a.

Hanson, T., \& Olson, P. (2018). Financial literacy and family communication patterns. Journal of Behavioral and Experimental Finance. https://doi.org/10.1016/j.jbef.2018.05.001.

Harrison, T., Marchant, C., \& Ansell, J. (2017). Young adults' financial capability. London, UK: Money Advice Service. https:// masassets.blob.core.windows.net/cms/files/000/000/525/origi nal/2016_08_YA_Deep_Dive_Report_Final.pdf

Hershey, D., Henkens, K., \& Van Dalen, H. (2010). Aging and financial planning for retirement: interdisciplinary influences viewed through a cross-cultural lens. International Journal of Aging and Human Development, 70(1), 1-38. https://doi.org/10.2190/ AG.70.1.a.

Johnson, E., \& Sherraden, M. (2007). From financial literacy to financial capability among youth. Journal of Sociology and Social Welfare, 34, 119-145. https://scholarworks.wmich.edu/cgi/viewc ontent.cgi? article $=3276 \&$ context $=$ jssw

Jorgensen, B., \& Salva, J. (2010). Financial literacy of young adults: The importance of parental socialization. Family Relations, 59, 465-478. https://doi.org/10.1111/j.1741-3729.2010.00616.x.

Kim, J., \& Chatterjee, S. (2013). Childhood financial socialization and young adults' financial management. Journal of Financial Counseling and Planning, 24, 61-79.

Kim, J., LaTaillade, J., \& Kim, H. (2011). Family processes and children's financial socialization. Journal of Family and Economic Issues, 32, 668-679. https://doi.org/10.1007/s10834-011-9270-3.

Knowles, J., \& Postlewaite, A. (2004). Do children learn to save from their parents? Unpublished Manuscript, University of Pennsylvania. Retrieved February 22, 2019 from https://pdfs.semanticsc holar.org/8968/cbc3ad668db114df0dcc86960becfc1a08b4.pdf.

Koposko, J. L., \& Hershey, D. A. (2016). Parental and early influence on expectations of financial planning for retirement. Journal of Personal Finance, 13, 17-27.

LeBaron, A., Hill, E., Rosa, C., Spencer, T., Marks, L., \& Powell, J. (2018). I wish: Multigenerational regrets and reflections on teaching children about money. Journal of Family and Economic Issues, 39(2), 220-232. https://doi.org/10.1007/s10834-017-9556-1.

Lee, J., \& Mortimer, J. (2009). Family socialization, economic selfefficacy, and the attainment of financial independence in early adulthood. Longitudinal and Life Course Studies, 1, 45-62. https ://doi.org/10.14301/llcs.v1i1.28.

Lusardi, A., \& Mitchell, O. (2014). The economic importance of financial literacy. Journal of Economic Literature, 52, 1, 358-378. Retrieved February 22, 2019 from https://www.jstor.org/stabl e/24433857.

Lusardi, A., Mitchell, O., \& Curto, V. (2010). Financial literacy amongst the young. Journal of Consumer Affairs, 44, 358-378. https://doi.org/10.1111/j.1745-6606.2010.01173.x.

Mill, J. (1843). A system of logic (Vol. 1). Cambridge: Cambridge University Press.

Office of National Statistics. (2017). Graduates in the UK labour market: 2017. Retrieved February 22, 2019 from https://www.ons. gov.uk/employmentandlabourmarket/peopleinwork/employment andemployeetypes/articles/graduatesintheuklabourmarket/2017.

Palaci, F., Jiménez, I., \& Topa, G. (2017). Economic cognitions among older adults: Parental socialization predicts financial planning for retirement. Frontiers in Aging Neuroscience, 9, 1-10. https://doi. org/10.3389/fnagi.2017.00376.

Polit, D., \& Beck, C. (2010). Generalization in quantitative and qualitative research: Myths and strategies. International Journal of Nursing Studies, 47, 1451-1458. https://doi.org/10.1016/j.ijnur stu.2010.06.004.

Ragin, C. (2014). The comparative method: Moving beyond qualitative and quantitative strategies. Oakland: University of California Press. ISBN 978-0-520-28003-8.

Robertson-Rose, L. (2016). Behavioural responses to automatic enrolment in workplace pension schemes. PhD Thesis, University of Edinburgh. http://hdl.handle.net/1842/33110.

Robertson-Rose, L. (2018). Good job, good pension. The influence of the workplace on retirement savings. Journal of Ageing and Society, 5, 4. https://doi.org/10.1017/s0144686x18000600. 
Saunders, B., Sim, J., Kingstone, T., Baker, S., Waterfield, J., Bartlam, B., et al. (2018). Saturation in qualitative research: exploring its conceptualization and operationalization. Quality \& Quantity, 52(4), 1893-1907. https://doi.org/10.1007/s11135-017-0574-8.

Serido, J., Shim, S., Mishra, A., \& Tang, C. (2010). Financial parenting, financial coping behaviors, and well-being of emerging adults. Family Relations, 59, 453-464. https://doi.org/10.111 1/j.1741-3729.2010.00615.x.

Shim, S., Barber, B., Card, N., Xiao, J. J., \& Serido, J. (2010). Financial socialization of first-year college students: The roles of parents, work, and education. Journal of Youth and Adolescence, 39, 1457-1470. https://doi.org/10.1007/s10964-009-9432-x.

Shim, S., Xiao, J. J., Barber, B., \& Lyons, A. C. (2009). Pathways to life success: A conceptual model of financial well-being for young adults. Journal of Applied Developmental Psychology, 30, 708-723. https://doi.org/10.1016/j.appdev.2009.02.003.

Tang, N. (2017). Like father, like son: How does parents financial behavior affect their children's financial behavior. Journal of Consumer Affairs, 51, 284-311. https://doi.org/10.1111/joca.12122.

Tang, N., \& Peter, P. C. (2015). Financial knowledge acquisition among the young: The role of financial education, financial experience, and parents' financial experience. Financial Services Review, 24(2), 119-137.

Torch, F. (2015). Analyses of intergenerational mobility: An interdisciplinary review. The Annals of the American Academy of Political and Social Science, 657, 37-62. https://doi.org/10.1177/00027 16214547476.
Walstad, W., Rebeck, K., \& Macdonald, R. (2010). The effects of financial education on the financial knowledge of high school students. Journal of Consumer Affairs, 44, 336-357. https://doi.org/10.111 $1 / \mathrm{j} .1745-6606.2010 .01172 . x$.

Ward, M. (2013). Parental education; attainment and sense of control in mid-late adulthood. Developmental Psychology, 49, 1407-1412. https://doi.org/10.1037/a0029557.

Webley, P., \& Lea, S. E. G. (1993). Towards a more realistic psychology of economic socialization. Journal of Economic Psychology, 14, 461-472. https://doi.org/10.1016/0167-4870(93)90027-i.

Webley, P., \& Nyhus, E. K. (2006). Parents' influence on children's future orientation and saving. Journal of Economic Psychology, 27, 140-164. https://doi.org/10.1016/j.joep.2005.06.016.

Xiao, J., \& O’Neill, B. (2016). Consumer financial education and financial capability. International Journal of Consumer Studies, 40, 712-721. https://doi.org/10.1111/ijcs.12285.

Publisher's Note Springer Nature remains neutral with regard to jurisdictional claims in published maps and institutional affiliations.

Lynne Robertson-Rose Ph.D. is a Career Development Fellow at the University of Edinburgh. Her research examines retirement savings behavior in workplace pensions. Lynne obtained her Ph.D. from the University of Edinburgh in 2016. 